\title{
Opportunities and Challenges of Purpose-Led Companies: An Empirical Study Through Expert Interviews
}

\author{
Anette von Ahsen ${ }^{1}$ (I) Kevin Gauch ${ }^{1}$
}

Published online: 29 July 2021

(c) The Author(s) 2021

\begin{abstract}
Purpose-Led Companies do not exclusively pursue profit-oriented goals, but also orient their actions towards a "higher" purpose. One example of this can be found in contributing to the achievement of social objectives. So far, only a few empirical studies analyze the opportunities and challenges associated with this approach. Accordingly, the present paper examines this approach by means of expert interviews in nine companies. The interview partners evidently believe that, by means of purpose-oriented management, their companies achieve both better financial performance and improved reputation, as well as increased employee motivation. Nevertheless, problems are also identified, in particular the possible trade-offs with profit targets, as well as conflicts due to contradictory stakeholder requirements.
\end{abstract}

Keywords Purpose-Led Company $\cdot$ Beyond profit $\cdot$ Corporate purpose

\section{Introduction}

"Purpose-Led Companies" not only focus on the earning profits, but also orient their decisions and actions towards a "higher" purpose. Thus, when presenting Vision 2020+, Joe Kaeser, CEO of Siemens, explained that for the first time, the company would be putting a purpose at the heart of its strategy (Höpner 2018). Empirical studies have shown that the above-mentioned example is not isolated, and that the concept of Purpose-Led Companies is widely used in business practice. In a survey of 474 executives, the Harvard Business Review (2015, p. 1) concludes that $46 \%$ of the companies surveyed established a strong sense of purpose. Of the 20 from a total of 30 companies in the German stock index (DAX) which participated in a study by Frondhöff and Scheppe (2019), 18 defined a purpose.

The question therefore arises as to the reasons behind this development. In a series of empirical studies, the (positive) relationship to corporate success is addressed. Purpose-Led

Anette von Ahsen

vonahsen@bwl.tu-darmstadt.de

Kevin Gauch

kevin.gauch@tu-darmstadt.de

1 Chair of Auditing \& Accounting, Department of Law $\&$ Economics, Technical University of Darmstadt, Hochschulstraße 1, 64289 Darmstadt, Germany
Companies, as the interviewed executives in the previously quoted study of the Harvard Business Review (2015, p. 37) estimate, have both more satisfied employees and customers, and display a higher growth than exclusively profit-oriented companies (see similar results from the EY Beacon Institute 2016; Accenture 2018). In addition, an increasing number of stakeholders expect companies to embrace this concept (Fontán et al. 2019, p. 81): “Even leaders who don't believe in it face pressure from board members, investors, employees, and other stakeholders to articulate a higher purpose" (Quinn and Thakor 2018, p. 81).

However, it is still the case that not much is known about the opportunities and challenges associated with PurposeLed Companies. So far, only a few empirical studies provide more in-depth insights into opportunities that companies associate with the purpose-related approach. Furthermore, the challenges that may be associated with such an approach remains somewhat unknown. This paper makes a contribution to the research on Purpose-Led Companies, and the associated opportunities and challenges. In the following section, a definition and the characteristics of purpose are considered. This is followed by a description of the opportunities and challenges associated with this concept from a business perspective. The next section provides an overview of previously published empirical studies, after which, the methodology of the present study and the results are 
presented. This is followed by a discussion of the results and a future research agenda.

\section{Definition and Characteristics of Purpose}

Despite the current importance of the concept for many companies, there is still a rather vague understanding of what is meant by Purpose-Led Companies, and there has been no generally accepted definition emerging (Gartenberg et al. 2019, p. 1; George et al. 2021; Hajdas and Kleczek 2021). One group of authors focuses mainly on the values behind the products and brands of companies. Accenture defines purpose as "The reason why something exists. For companies, it is the foundation of every experience. It is the underlying essence that makes a brand relevant and necessary" (Accenture 2018, p. 6). A purpose does not always have to be "pro-social" (Gartenberg et al. 2019, p. 3). Rather, the aim is to show the purpose for which the company was founded. A well-known example of this is Apple Inc. (Kramer 2017).

A second group of authors have a slightly different focus and do not primarily address company products or services, but the entirety of the environmental and social consequences of its actions. This interpretation of the term has a close relationship to the concept of Corporate Social Responsibility (CSR). According to the European Commission, CSR is defined as "the responsibility of enterprises for their impacts on society" (European Commission 2011, p. 6). $\mathrm{Zu}(2019$, p. 2) also refers to this connection: "I think that the purpose revolution is the uninterrupted wave of CSR revolution and debate of shareholder and stakeholder theories" (see similarly Pruzan 2001, pp. 57-59; Steenberg and Sharma 2020). However, such a combination of CSR and purpose is also criticized, for example, by Pontefract (2017), who emphasizes that CSR is a crucial component of an organization's business ethos, but not its purpose.

This paper follows the definition of Henderson and van den Steen (2015, p. 327), according to which a purpose is "a concrete goal or objective for the firm that reaches beyond profit maximization" (see similarly Bartlett and Goshal 1994 , p. 8). However, this is not about individual activities, such as donations or sponsoring, but about the "raison d'être" (Dahlmann et al. 2020, p. 1) of a company, which is at the heart of its activities and provides a background for all its activities. Table 1 shows examples of very different purposes.

A broad spectrum of purposes can be observed in practice and in theory. In startups, the formulation of purpose is often directly linked to the founding of the company (Rode and Vallaster 2005, p. 132; Kautonen et al. 2020). In established companies, there is often a return to the goals that the company pursued when it was founded (Oechsle and Henderson 2000, p. 76).

\section{Opportunities and Challenges Confronting Purpose-Led Companies compared to Traditional Companies}

In the literature, the pursuit of a purpose is primarily associated with various opportunities for companies. It is usually argued that the implementation of a purpose enhances corporate performance (Fontán et al. 2019, p. 107; Deloitte 2014 , p. 5). A particularly important benefit is that the reputation of a company can be enhanced by pursuing a purpose (Oechsle III 2002, p. 181; Collins and Saliba 2020). A good reputation has long been seen as an important success factor

Table 1 Examples of corporate purpose

\begin{tabular}{lll}
\hline Company & Industry & Purpose \\
\hline Airbus & Aerospace & "We pioneer sustainable aerospace for a safe and united world" (Airbus 2021) \\
Disney & Leisure & "To create happiness for others" (Jones 2018) \\
IAG & Insurance & "Make your world a safer place" (IAG 2021) \\
ING & Finance & "Empowering people to stay a step ahead in life and in business" (ING 2021) \\
Kellogg's Company & Food processing & "Nourishing families so they can flourish and thrive" (Kellogg's Company 2021) \\
Mercedes Benz Cars & Automotive & "First move the world" (Daimler 2021) \\
Nestlé & Food processing & "Enhancing quality of life and contributing to a healthier future." (Nestlé 2021) \\
Patagonia & Outdoor Clothing & "We're in business to save our home planet" (Patagonia 2021) \\
Philips & Electronics & "We strive to make the world healthier and more sustainable through innova- \\
Southwest Airline & tion" (Radley 2016; Philips 2021) \\
Unilever & Aviation & "Connect people to what's important in their lives through friendly, reliable, and \\
Zappos & low-cost air travel" (Southwest 2020) \\
\hline
\end{tabular}


for companies (Helm 2007). If the reputation of a company is improved by a purpose orientation, this can contribute to financial success. In addition, and partly related to this, it is argued that a corporate purpose can, for example, lead to increased employee satisfaction. A large number of studies have shown that employees who see their job as meaningful, perform better and identify more strongly with their company (Liden et al. 2000; Michaelson et al. 2014). The extent to which these relationships are more pronounced in Purpose-Led Companies than in traditional ones can have a positive impact on success (Bartlett and Goshal 1994; Hendersen and van den Steen 2015). A similar relationship can exist with regard to customer loyalty and satisfaction. Various studies have concluded that customers show greater willingness to buy from and greater loyalty to a company if it is perceived as CSR-oriented (Du et al. 2007a, b). If the purpose is oriented towards aspects of CSR or is perceived as positive by customers for other reasons, similar effects may occur. However, Mañas-Viniegra et al. (2020) conclude in their study that a corporate purpose will not have such a positive effect on customers if the credibility of the company is rated low due to negative events in the past.

In addition to the benefits that arise for companies, the purpose approach is associated with various opportunities for society as a whole. The commitment to a purpose is seen as part of a development that enables companies address environmental and social challenges in society (EY Beacon Institute 2016; Pontefract 2017; Zu 2019, p. 3; Busch 2021; By 2021).

However, pursuing a purpose can also cause challenges for the company. The risk of negative effects on financial success can vary greatly, depending on the industry in which the company operates and the nature of the purpose. For example, it is possible that profitable aspects of the business that contradicts the purpose may have to be abandoned. An example of this is CVS Corporation, a retail company in the pharmaceutical industry in the USA. The company stopped selling tobacco products in 2014 that were in conflict with the company's purpose of "helping people on their path to better health" (CVS Health 2020). Such contradictions can lead exclusively financially-oriented investors fearing the negative effects of the purpose on the financial success of the company. Segrestin et al. (2015, 2016; see also Bueren 2019) address the extent to which companies that are required by law to operate in a shareholder-oriented manner, such as stock corporations, can pursue a purpose if this also implies some financial losses. In the meantime, a number of legal forms have emerged for such companies that do not primarily or exclusively want to operate for profit but for purpose (Mac Cormac et al. 2014; Levillian and Blanche 2019, p. 637; Kolk and Lenfant 2016; Stubbs 2017; Mion et al. 2020; Fleischer 2021). In summary, Segrestin et al. (2016) speak of "profit-with-purpose corporations". This illustrates that it cannot be assumed that Purpose-Led Companies are economically more successful than traditional companies in every case. However, there are indicators that companies with a higher environmental performance also achieve better financial results (Kalkavan 2020; Okafor et al. 2021). If these findings are applied to the purpose concept, it is quite conceivable that companies with sustainability-oriented purpose can also outperform.

Another problem for Purpose-Led Companies might emerge within the company, namely that the purpose "can distract managers from a brand's primary business needs" (Vilá and Bharawaj 2017, p. 97). In addition, employees may be more likely to seek their purpose outside the company and may therefore not be open to the idea of a corporate purpose (Prat and Ashforth 2003, p. 325). It is also possible that they do not agree with the purpose, or at the very least feel it is imposed from above, and therefore reject it (Cardona et al. 2019).

All things considered, this scenario may result in many opportunities, but also challenges for Purpose-Led Companies.

\section{Empirical Studies on the Opportunities and Challenges for Purpose-Led Companies}

By now, several empirical studies have been published on the opportunities and challenges confronting Purpose-Led Companies. Table 2 provides an overview.

As Table 2 shows, these studies are multifaceted and use various methodological approaches. In the following section, key findings on the motives and challenges that can be associated with a commitment to a purpose, from a corporate perspective, are summarized.

Edelmann (2012) concluded as early as 2012 that $72 \%$ of the customers they surveyed would prefer "purpose organizations" (Edelmann 2012, p. 3; similarly, Korn Ferry 2016; Accenture 2018; Villela et al. 2019; Collins and Saliba 2020). This applies only if they regard the approach as credible: "they'll never want purpose-wash communications" (Radley Yeldar 2018, p. 32; see also similarly EY Beacon Institute 2016, p. 31; Vilá and Bharadwaj 2017).

The impacts of a purpose on company employees are also addressed in several studies (Deloitte 2014; Nga Wai Chan 2015; The Energy Project and HBR 2014; Harvard Business Review 2015; LinkedIn and Imperative 2016; Korn Ferry 2016; PWC 2016). The study from The Energy Project and HBR (2014), for example, involved 20,000 participants on HBR Online. The results showed, among other things, that employees who found purpose in their work, stated significantly more often that they wanted to remain in their organization, were satisfied with their work and committed. The problem of "inner dismissal" also played a much smaller role 
Table 2 Empirical studies on purpose-led companies

\begin{tabular}{|c|c|c|}
\hline Authors & Design & Focus \\
\hline Edelmann (2012) & Online survey, 8000 customers in 16 countries & $\begin{array}{l}\text { Consumer attitudes towards the purpose of brands } \\
\text { and companies }\end{array}$ \\
\hline Nga Wai Chan (2015) & $\begin{array}{l}\text { Online survey with } 67 \text { social purpose enterprises; } \\
\text { Interviews with } 11 \text { managers and directors }\end{array}$ & $\begin{array}{l}\text { Impact of the purpose on commitment to work and } \\
\text { general well-being of the employees }\end{array}$ \\
\hline The Energy Project and HBR (2014) & $\begin{array}{l}\text { Online survey, 20,000 employees from different } \\
\text { sectors }\end{array}$ & $\begin{array}{l}\text { Needs of employees in the working world; impact of } \\
\text { purpose on employee engagement }\end{array}$ \\
\hline Deloitte (2014) & $\begin{array}{l}\text { Online survey, } 300 \text { executives and } 753 \text { employees } \\
\text { in companies with more than } 100 \text { employees }\end{array}$ & $\begin{array}{l}\text { Impact of a strong purpose on stakeholder confi- } \\
\text { dence and investor willingness to invest }\end{array}$ \\
\hline Harvard Business Review (2015) & $\begin{array}{l}\text { Online survey, } 474 \text { executives from different com- } \\
\text { panies worldwide }\end{array}$ & Implementation of a purpose in business practice \\
\hline PWC (2016) & $\begin{array}{l}\text { Dual survey, } 1510 \text { employees and } 502 \text { business } \\
\text { leader }\end{array}$ & $\begin{array}{l}\text { Purpose and leadership; impact of purpose on } \\
\text { employees engagement }\end{array}$ \\
\hline EY Beacon Institute (2016) & Literature review; about 6 interviews & $\begin{array}{l}\text { Purpose as strategic impetus, guide for corporate } \\
\text { transformation and long-term value creation }\end{array}$ \\
\hline LinkedIn und Imperative (2016) & $\begin{array}{l}\text { Online survey, 26,151 LinkedIn members world- } \\
\text { wide }\end{array}$ & The importance of purpose in the workforce \\
\hline Korn Ferry (2016) & $\begin{array}{l}\text { Interviews with } 30 \text { founders, CEOs, and senior } \\
\text { executives at consumer companies with visible } \\
\text { and authentic purpose }\end{array}$ & $\begin{array}{l}\text { Impact of purpose on financial performance, leader- } \\
\text { ship and employee engagement }\end{array}$ \\
\hline White et al. (2017) & Interview with the $\mathrm{CEO}$ of Barclays & Implementation of Purpose and internal challenges \\
\hline EY Beacon Institute (2017) & Survey with 1470 business leaders & $\begin{array}{l}\text { Purpose helps companies navigate in today's world; } \\
\text { purpose drives value in both the short- and long- } \\
\text { term }\end{array}$ \\
\hline Accenture (2018) & Online survey, 29,530 customers worldwide & $\begin{array}{l}\text { Consumer expectations of corporate purpose and } \\
\text { possibilities for implementation }\end{array}$ \\
\hline DDI (2018) & $\begin{array}{l}\text { Survey with 25,812 leaders and } 2547 \text { HR profes- } \\
\text { sionals }\end{array}$ & $\begin{array}{l}\text { Purpose-driven leadership drives financial perfor- } \\
\text { mance; purpose as a driver of employee engage- } \\
\text { ment }\end{array}$ \\
\hline Muñoz et al. (2018) & Interview with $14 \mathrm{~B}-$ Corps entrepreneurs & $\begin{array}{l}\text { Relationship between purpose and organization; } \\
\text { purpose definition and market validation }\end{array}$ \\
\hline Radley Yeldar (2018) & $\begin{array}{l}\text { Scoring model of the PwC100 and FTSE Eurofirst } \\
100\end{array}$ & $\begin{array}{l}\text { Communication (and implementation) of company } \\
\text { purpose; degree of fulfilment }\end{array}$ \\
\hline The British Academy (2018) & Roundtables with 100 experts & $\begin{array}{l}\text { Development of } 9 \text { principles for implementing a } \\
\text { purpose }\end{array}$ \\
\hline Hsieh et al. (2018) & 24 interviews with executives & $\begin{array}{l}\text { Difference between social purpose and corporate } \\
\text { purpose; role of social purpose and corporate } \\
\text { purpose for companies }\end{array}$ \\
\hline Frondhöff and Scheppe (2019) & Survey, 20 of 30 DAX companies & Implementation of purpose in the DAX \\
\hline Gartenberg et al. (2019) & $\begin{array}{l}\text { Online survey with 500,000 employers and } \\
\text { employees }\end{array}$ & $\begin{array}{l}\text { Relationship between purpose and financial perfor- } \\
\text { mance }\end{array}$ \\
\hline Porter Novelli (2019) & Online survey, 1193 Americans & $\begin{array}{l}\text { Purpose improves consumer loyalty and companies } \\
\text { reputation }\end{array}$ \\
\hline Stroehle et al. (2019) & Nine interviews; four case studies with companies & $\begin{array}{l}\text { Relevance of the British Academy Principles for } \\
\text { Purposeful Businesses (see The British Academy } \\
\text { 2018) }\end{array}$ \\
\hline ANA (2020) & Online survey with 259 B2B professionals & $\begin{array}{l}\text { Stated purpose vs. activated purpose gap; Communi- } \\
\text { cating purpose; purpose empowers Stakeholders }\end{array}$ \\
\hline Collins and Saliba (2020) & $\begin{array}{l}\text { Four interviews with representatives of small } \\
\text { and medium size enterprises; Survey with } 110 \\
\text { participants }\end{array}$ & $\begin{array}{l}\text { Purpose improves the relationship between stake- } \\
\text { holders and the company; purpose before profit } \\
\text { improves customer loyalty }\end{array}$ \\
\hline Lleo et al. (2020) & $\begin{array}{l}\text { Survey with } 862 \text { employees from eight Spanish } \\
\text { companies }\end{array}$ & $\begin{array}{l}\text { Purpose implementation; measuring the intensity of } \\
\text { purpose }\end{array}$ \\
\hline
\end{tabular}


here (The Energy Project and HBR 2014, p. 7). The concerns expressed in the literature that some employees may be hesitant to pursue a corporate purpose, are also barely analyzed in the empirical studies.

A study by Deloitte (2014) also addresses the assessments of managers and employees regarding the relevance of a purpose for the financial success of a company (similarly DDI 2018). More than 1,000 managers and employees were surveyed, whereby two groups were formed, those participants who stated that they worked in a company with a strong purpose and those who did not. $82 \%$ of participants working for an organization with a strong purpose said they were confident that their organization would grow that year, compared to only $48 \%$ of respondents from companies without such a purpose. These companies were also significantly more optimistic about the organization's ability to stay ahead of and overcome industry problems ( $83 \%$ vs. $42 \%$ ) and to outperform the competition (79\% vs. $47 \%$ ). Gartenberg et al. (2019, pp. 2-3) conclude that above all, "high purpose-clarity organizations exhibit higher financial performance in the future, especially when these beliefs are held by midlevel employees".

Only a few studies examine potential challenges in addition to positive relationships between purpose and financial success. In the survey of 474 executives conducted by the Harvard Business Review (2015), 14\% of participants identified three main problems: "short-term shareholder pressure, systems and infrastructure that are not aligned with long-term purpose, and the lack of performance targets and incentives aligned with purpose" (Harvard Business Review 2015, p. 8; see also similarly EY Beacon Institute (2016, p. 21).

Although the empirical studies have different orientations, it is notable that the pursuit of purpose has become a relevant topic in business practice, and that opportunities are perceived, above all, for a more effective achievement of corporate financial goals. Against this background, the present study aims to analyze the opportunities and particularly the challenges of Purpose-Led Companies in greater depth. Expert interviews will be conducted for this purpose. In particular, the study participants will be asked to assess the impact of a Purpose-Led Company on employees and customer relations, as well as on financial aspects, e.g., any trade-offs that may be required between profit generation and purpose, based on their professional experience. Conducting the study by means of expert interviews enables both querying the assessments on the basis of a scale and considering the background to the responses, also, if necessary, examining individual aspects in greater depth.

\section{Empirical Study: Analysis of Potential Opportunities and Challenges for Purpose-Led Companies}

\section{Objectives of the Study and Research Methodology}

Most of the available empirical studies on Purpose-Led Companies are designed on a large scale. By contrast, semi-structured guideline expert interviews (Witschey et al. 2013; Flick 2018) with companies were chosen as the research design for this study. This made it possible to explore the potential opportunities and challenges for Purpose-Led Companies in more detail with the experts, for example by asking for justifications for answers and following up on ambiguities. Expert interviews also allow the interviewer to formulate follow-up questions in response to the interviewees' answers (Kallio et al. 2016). At the same time, interviewees can respond flexibly to questions, according to their specific experience and knowledge.

In addition, studies published to date have primarily examined the opportunities associated with Purpose-Led Companies. They mainly have examined manager assessments of the potential of this concept to increase employee and customer satisfaction, as well as the financial success of the company. By contrast, possible challenges and obstacles are discussed to a lesser extent. This also applies to previous qualitative studies, such as the case studies of Villela et al. (2019) as well as Collins and Saliba (2020) and the expert interviews of Pechmann et al. (2019). The present qualitative study contributes to closing these research gaps by conducting expert interviews with companies. In particular, insights are gained with regard to the following questions:

- What advantages do the interview partners see in a Purpose-Led Company compared to traditional companies? What importance do the experts attach to the various opportunities?

- What are the specific challenges and obstacles associated with a Purpose-Led Company? What relevance do decision makers assign to the different problems?

Based on information from their websites, 14 companies were identified as having either implemented a purpose or were in the process of doing so. For two other companies, it was also known through information available during a conference or an exhibition, that they had implemented a purpose or had at least developed a comprehensive concept in this respect. In total, therefore 16 companies were considered as potential participants in the study and contacted by email. Nine of these companies agreed to participate in the study. As a result, 
nine semi-structured expert interviews were conducted based on an interview guide (see Appendix). The interviews lasted between half an hour and one hour and were conducted by telephone, and in partly in person between November 2018 and May 2019. For each interview, a case study protocol of the experts' answers was prepared. In order to ensure the authenticity and internal validity of the results, and to exclude subjective interpretations (Yin 2014), the research results were presented to the experts following the interviews, and discussed with them in a second telephone call and via e-mail. If necessary, a revised version of the protocols was sent to the interview participants, so that a version of the protocol, approved in writing by the respondents, could then be used for evaluation.

Seven German and two Swiss companies were surveyed. In the eight companies that have either already implemented a purpose or are currently doing so, the interviewees had initiated the implementation process and/or were or are significantly involved in the implementation. In the ninth company, a concept had already been developed with the participation of the interviewee, and was being evaluated at the time of the interview, in order to decide on its implementation. Table 3 shows the sector allocation of the participating companies, as well as the number of interviews per sector, including two Limited Liability Companies (GmbHs), six stock corporations (AG) and one Societas Europaea (SE). These are therefore not companies with a hybrid legal form in which a corporate purpose is anchored in the articles of association.

Both the content and the origin of the purpose yield considerable differences. For example, the start-up was founded explicitly to enable children to communicate safely in the Internet. In three of the six companies that have already implemented a purpose, it was formulated on the basis of the company's original goals and objectives (Interview ID No. $1,5,8)$. For example, the purpose of one of the companies in the food processing industry is "Enhancing quality of life and contributing to a healthier future". This purpose is derived from the original objective of reducing infant mortality through the sale of breast milk substitutes. One company did not return to its original objective, but the purpose was newly developed, based on a proposal from the marketing department.

The organizational procedures are also inconsistent. In two cases, top management initiated the establishment of the purpose (Interview ID No. 2 and 8), whereas the concrete development of the purpose was the responsibility of the communications department. Both experts told us from their own experience they consider this as the necessary procedure. By contrast, in two other companies, members of middle management drove the initiative (Interview ID No. 1 and 3) and in one case the formulation of a purpose was initiated by a "Community Building Process" (Interview ID No. 7). In all cases, the final decision was made by top management. In two cases, no information on the history of the purpose was available, whereas in the start-up the founders defined the purpose. In the company with current no defined purpose, discussions are ongoing between HR and management for a proof of concept (Interview ID No. 6).

\section{Opportunities of a Purpose-Led Company}

The interview participants were asked about their experiences concerning the opportunities that Purpose-Led Companies have, compared to companies without an explicit purpose. A scale of $1=$ "fully agree", $2=$ "somewhat agree", $3=$ "neither nor", $4=$ "somewhat disagree" to $5=$ "disagree" was used and in each case, the participants were also asked about the background of the assessment. The results are shown in Fig. 1.

Five out of nine interview partners agreed "fully" or "somewhat" that a purpose has a positive effect on the financial success of the company. At least four experts did not see a relationship in this context, or did not agree to some extent. "We are confident that it is precisely the pursuit of purpose that will ensure long-term success. If we don't offer solutions to social challenges, we won't be successful in the market in the long term" (Interview ID No.

Table 3 Description of the data sample

\begin{tabular}{lllll}
\hline Industry & Interview-ID & Size & Position & Status quo of the implementation of a purpose \\
\hline Chemicals & 1 & Big & Sustainability & Purpose is implemented \\
Chemicals & 2 & Big & Communication & Purpose is in development \\
Industry & 3 & Big & Sustainability & Purpose is in development \\
Industry & 4 & Big & Head of Technology & Purpose is implemented \\
IT & 5 & Start-up & Founder & Purpose is implemented \\
IT & 6 & Medium & HR-Manager & Implementation of purpose is considered \\
IT & 7 & Big & Solution Owner & Purpose is implemented \\
Food processing & 8 & Big & Communication & Purpose is implemented \\
Pharmaceuticals & 9 & Big & HR-Manager & Purpose is implemented \\
\hline
\end{tabular}




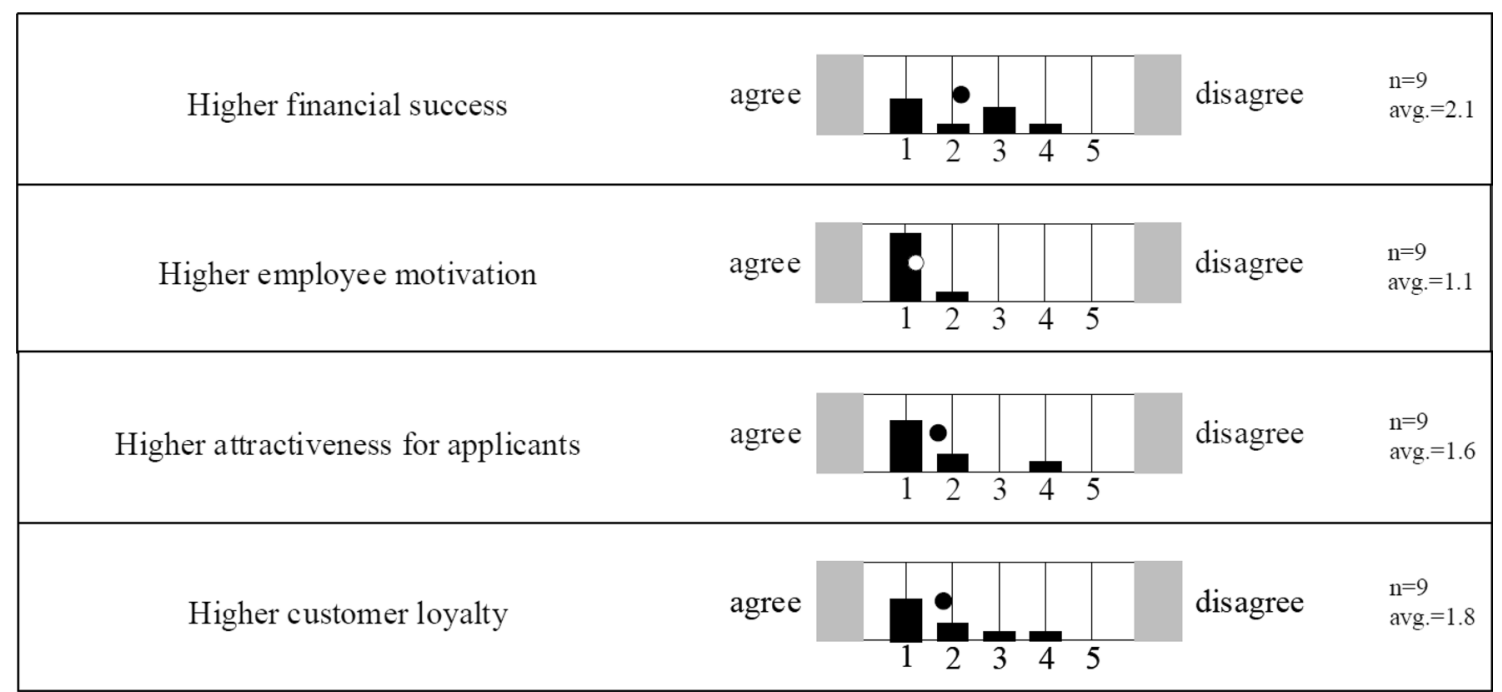

Fig. 1 Opportunities confronting Purpose-Led Companies

1). By contrast, another expert reports that investors see the purpose only as a nice accessory (Interview ID No. 8).

However, all interviewees rated higher employee motivation as an important positive effect of the company's purpose. Several experts pointed out that employees in Purpose-Led Companies need less guidance because they are more self-directed. According to one expert, older managers in his company often have problems dealing with new, autonomous structures, as they are familiar with and thus prefer specific instructions and controls (Interview ID No. 6). Many employees also take pride in contributing to solving a major problem through their work-life activities. A higher degree of self-responsibility creates a dynamic of its own that has a positive effect on the company. In several interviews, however, it was also pointed out that it is necessary to "pick up" the employees early in the process and that a joint formulation of the purpose in workshops is relevant in this respect. In addition, recognizable support of the purpose by management is necessary. It was also mentioned several times that the purpose had to be designed for the long term and communicated regularly to stakeholders.

The interviews reveal that the impact of the purpose on potential job applicants is considered almost as important as the motivation of the current workforce. From their experience, several interviewees emphasized the usefulness of informing potential future employees about the company's purpose during the application process and of elaborating on the topic during "onboarding" events. "Our purpose is sometimes cited by job applicants in interviews as a reason for applying" (Interview ID No. 9). However, they also mentioned that a requirement for this is a good fit between the values of the applicant and those of the company (see also the section "Challenges Confronting a Purpose-Led Company").

Seven of nine interview partners "fully" or "somewhat" agreed that a purpose leads to higher customer loyalty. When asked about further advantages of a Purpose-Led Company, two interview partners mentioned positive feedback that they received within and beyond their company, especially on the public reputation of the company (Interview ID-No. 1 and 3). As one expert emphasized: "the chemistry industry is often seen as a problem, but should rather be understood as a problem solver" (Interview ID No. 1). The Purpose-Led Company concept is seen here as an opportunity to help the company create a change of mindset and improve its reputation.

It is interesting to observe that the interviewees largely agree on the advantages of being a Purpose-Led Company, especially in the area of employee motivation and acquisition, as well as regarding customer loyalty. On the other hand, the assessments regarding the financial success of a company are more varied.

\section{Challenges Confronting a Purpose-Led Company}

Next, based on their experience within the company, the interview partners were asked about the extent to which Purpose-Led Companies face challenges compared to traditional companies. The results are shown in Fig. 2.

In five out of nine cases, the main disadvantage of Purpose-Led Companies was regarded as the possible tradeoff between profit and purpose. The interviews showed that individual decisions can at least help to achieve the purpose, but not the profit. Such conflicts have to be analyzed and taken into account when making decisions. "But to achieve the 


\begin{tabular}{|c|c|c|c|}
\hline Conflicts with financial goals & agree & disagree & $\begin{array}{l}n=9 \\
\text { avg. }=3\end{array}$ \\
\hline $\begin{array}{l}\text { Deterrence of purely } \\
\text { financially-oriented investors }\end{array}$ & agree & disagree & $\begin{array}{l}\mathrm{n}=9 \\
\text { avg. }=2.7\end{array}$ \\
\hline Negative employee attitude & agree & disagree & $\begin{array}{l}\mathrm{n}=8 \\
\text { avg. }=2.8\end{array}$ \\
\hline Contradictory stakeholder requirements & agree & disagree & $\begin{array}{l}\mathrm{n}=9 \\
\text { avg. }=2.3\end{array}$ \\
\hline
\end{tabular}

Fig. 2 Potential challenges of Purpose-Led Companies

purpose, we cannot give up every pursuit of profit" (Interview ID No. 5). Several experts pointed out that a functioning purpose is a long-term investment, and that particularly in the short-term, declines in profit must be accepted. One interviewee emphasized, "As a stock corporation, one is trapped in a corset when pushing such topics, since decision alternatives are evaluated primarily from an economic perspective. It is easier for start-up companies; here it can be specified in the articles of association that certain social or ecological goals may be pursued even if they conflict with economic goals" (Interview ID No. 7).

The deterrence of purely financially-oriented investors was considered a potential disadvantage of a Purpose-Led Company by four of the nine interviewees. It was discussed several times that this could possibly change in the future, as investors also increasingly take a longer-term view. However, one interviewee experienced that this depends substantially on the specific content of the purpose. In discussions with investors it became clear that they were most likely to be positive about sustainability-oriented and especially ecologically-oriented purposes. "Nevertheless, the investors' pursuit of profit is present. Therefore, the purpose is justified in our company with concrete, quantifiable goals and business cases" (Interview ID No. 1). By contrast, other purposes are still often viewed very skeptically by investors.

Four out of eight participants regarded a negative employee attitude as a potential problem for Purpose-Led Companies. One interviewee emphasized that especially in companies with a long history, this change process can encounter barriers among employees (Interview ID No. 6). In two interviews with managers from large companies, it was pointed out that due to the existing variety of cultures and work situations, not all employees are familiar with the purpose (Interview ID-No. 2 and 8). As a consequence, in one case, the expert and his team developed a "sub-purpose" that does not conflict with the company's purpose, but modifies it to better fit the needs of the specific department.

A question that has only been addressed marginally in most empirical studies and also in the literature so far, is how to deal with those employees who cannot identify with the company's purpose. Five participants in the study explained that not all of their employees are required to agree with the purpose, which would anyway be unrealistic, especially in large companies. However, this depends on the degree of disagreement. Seven interview participants regularly determine the degree of agreement with the purpose through interviews or surveys. Several interviewees reported difficult situations that arose because employee attitudes clearly contradicted the company's purpose. As one interviewee put it: "If employees cannot adopt the purpose for themselves, it should be discussed openly with them and opportunities for further development examined. Ultimately, however, consideration must also be given to transferring the employee to an area where the purpose does not play such a major role" (Interview ID No. 7). Another interviewee emphasized that in his company, the higher an employee's position in the company hierarchy, the more important a commitment to purpose is considered and encouraged (Interview ID No. 8). Managers in particular need to internalize the purpose in order to disseminate it within the company.

Two interviewees considered another possible cause of employee rejection as the fact that the term "purpose" is often overused, such as in training sessions and events, particularly when those events are actually about completely different issues. Another perceived issue is that a purpose orientation is seen as a mere marketing measure. As one 
expert emphasizes: "The term "purpose" is sometimes used in a negative sense by employees [...] because companies call themselves "purpose-led", even though this is only an (internal or external) marketing strategy" (Interview ID No. 7). This problem is especially evident when the responsibility is anchored in the communication department. In this context, one participant spoke of "purpose-washing", which could seriously damage the company's reputation (Interview ID No. 1). For this reason, several interviewees argued that the purpose should originate from top management and/or corporate strategy. Further development of the compensation systems is additionally necessary, to the extent that not only profit-oriented indicators are implemented for variable salary components, but also indicators oriented to the company's purpose. It is important to make clear that this is not "just lip service".

It is interesting that contradictory stakeholder requirements were mentioned by seven study participants as a major problem for Purpose-Led Companies. Several interviewees emphasized that, for example, supply chain partners acting contrary to the company's purpose could endanger its credibility. In addition, different stakeholders may have quite different ideas about the content of the corporate purpose, depending on their values, beliefs and preferences.

Most of the participants in the study cited the measurement of success as a further challenge. Purpose-Led Companies not only have to measure their financial success, but also the achievement of purpose, and its internalization by employees. Measuring the achievement of purpose was regarded particularly as an unsolved problem in several of the participating companies. One interviewee emphasized: "Of course, on the one hand there is definitely an economic demand on the company. But we also measure our success by the number of children protected, specifically through the number of chat users and messages. We also measure our success by the ratings and experiences of children and parents" (Interview ID No. 5). Another participant mentioned that the purpose is indirectly monitored in their company by means of regular employee surveys. In these surveys, the purpose is examined in different facets and with different degrees of approval (Interview ID No. 1). However, only the internal effect can be checked in this way.

In short, the interviews reveal that Purpose-Led Companies have to overcome a number of challenges.

\section{Discussion}

Increasingly, companies are presently committing themselves to a purpose that goes beyond the earning profits. This study provides in-depth insights into the motives of companies, and the challenges associated with this approach, that may prevent the concept from being widely used.
With regard to the possible advantages of Purpose-Led Companies compared to those that pursue exclusively economic goals, the interviews yield largely similar results to the empirical studies that have so far been conducted. In particular, the approach is associated with higher employee motivation, as well as greater customer loyalty and an improved corporate reputation. However, there are different opinions regarding whether greater financial success of the company can be expected.

The results regarding potential challenges for PurposeLed Companies provide some possible explanations. The problem of deterring financially-oriented investors by pursuing a purpose is seen a good example. This is particularly true for companies with the legal form of a stock corporation (AG) or a Societas Europaea (SE), which were the focus of our study. With regard to CSR-oriented corporate goals, a large number of empirical studies are already available, but with contradictory results (Häfner et al. 2017). However, such studies show that investors are increasingly expecting companies to adopt a sustainability orientation, particularly with regard to climate targets (Kiron et al. 2017; MirallesQuiros et al. 2017 and Pinney et al. 2019), partly because this can reduce future risks. At least for companies with a purpose such as reducing greenhouse gas emissions, there may be less of a problem in the future of deterring investors. However, as the interviews also showed, the situation is much more difficult for companies with other purposes. This illustrates the problem of establishing a general relationship between the purpose of a company and its success. Due to the wide range of possible purposes, this can only be analyzed effectively for each individual case.

The interviews demonstrated that the successful implementation of a purpose depends on whether it is perceived as a credible approach by the internal and external company stakeholders. For this reason, it seems necessary to conduct a comprehensive and continuous dialog with internal and external stakeholders. This is a prerequisite for analyzing their changing needs and developing communication strategies on this basis, as already called for in the ethical branding approach (Fan 2005). However, it is important to note that interaction and communication with different stakeholders, e.g., employees and customers, cannot be identical and that some differentiation is necessary. Employees are not customers, and their requirements are much more complex (Annweiler 2018).

However, the question is not only how to convince the various stakeholders of the credibility and content of the purpose, but a true paradigm shift "from positioning to purpose" (Jones 2012, p. 77) is now also being discussed. This includes the approach and philosophy that stakeholders can influence corporate purpose: "As employees give voice to their concerns and stage walkouts or other forms of more tacit protests, how do firms evaluate or reevaluate 
their existing purpose?" (George et al. 2021). Something similar can be discussed for the claims of other stakeholders. For the corporate purpose, this raises the overall question of the extent to which it reflects or should reflect the opinions and expectations of a company's stakeholders: "The idea of shared and aligned purpose should never be perceived as akin to soldiers standing in an artificially rigid order" (Kramer 2017, p. 7).

Against this background, however, a number of challenges arise for companies: Firstly, there is the question of how to deal with potentially contradictory stakeholder requirements. In the present study, it became clear that several interviewees regard this as a problem. On the other hand, the requirements of stakeholders can change over time. If the purpose is adapted to such developments, there is a risk that the concept will become watered down and perceived as "purpose washing". Future research projects could address such aspects of "purpose dynamics" and approaches for companies to meet this challenge.

This is all the more so against the backdrop of digitalization and the prevailing importance of social media: stakeholders can now, for example, publish statements and claims against companies that are visible from afar (Mitchell 2012; Asmussen et al. 2013). In this context, Lies (2020) points out that increasingly "aesthetic" requirements, which in the past referred primarily to the products themselves, are now also being extended to management processes. In addition, digitalization makes it possible for stakeholders to monitor the fulfillment of a purpose on a daily basis. "Thus, the transparency, interaction and real-time marketing claims of society 4.0 requires aesthetic, i.e. ethical, competencies across the management of all business units" (Lies 2021, p. 112, also see George et al. 2021, p. 15). At the same time, the statements of stakeholders in social media enable innovative approaches for companies, e.g., to identify customers whose values correspond with the company's purpose and then to address them with appropriate online marketing (Mishra 2020). For an overview of different approaches to brand management "in a hyperconnected world", see also Swaminathan et al. (2020).

In order to ensure that purpose is not just a hollow marketing concept, various forms of cooperation may become more important in the future. Increasingly, NGOs support companies "by advocating and advising the business sector on how to reconsider and broaden their fundamental "raison d'être". The aim of these private sector actors is to create "purpose driven businesses" that integrate social and environmental objectives into their organizational purpose, rather than pursuing a singular focus on financial objectives" (Dahlmann et al. 2020, p. 1). Such a "purpose ecosystem" can help to support a sustainability-oriented transition of society (Kivimaa et al. 2019; Köhler et al. 2019). An example of such an organization is the Science Based Targets
Initiative, which certifies corporate targets for the reduction of greenhouse gas emissions if they contribute sufficiently to achieving the two-degree goal (Faria and Labutong 2019; SBTi 2020). Other examples include the "We Mean Business Coalition" and "Future Fit Business". The B Corp Certification (Bauer and Umlass 2017; Stubbs 2017; Villela et al. 2019) also belongs to this category. Such cooperation can help to improve the reputation of companies. In addition to "Sustainability Target Initiatives", Dahlmann et al. (2020) distinguish between two further purpose ecosystems: on the one hand, "Impact Investment", which includes CSR-oriented investors and rating agencies, and "Business Purpose Change Agents", i.e., organizations that aim to fundamentally change the business models of companies. Depending on their respective purposes, a way for companies to achieve their objectives may be to find such partners in the non-profit sector who can support the achievement of the purpose and its communication in this context.

Within their own company, the interviewees saw a particular need for action that would increase their credibility and align decisions with their purpose. The question of how to deal with those employees who cannot or do not identify with the company's purpose also plays an important role. Based on the interviews, it was clear that this is a problem that has been difficult for companies to solve so far. Ultimately, concepts can be used in this context that have already been intensively discussed in connection with the topic of corporate culture (Bauer et al. 1998; Fink and Moeller 2018; Nicholson 1984). An appropriate design of governance structures and incentive systems may also constitute an important approach.

In addition, the importance of innovative legal forms for companies that are explicitly created to achieve a purpose is likely to increase in the future. At present, however, it remains difficult to predict how widespread these legal forms will become in the future and what advantages and disadvantages this will have for companies who pursue a purpose.

When interpreting the results, the limitations of the present study must be taken into account: The results are based on nine expert interviews, so that the usual limitations associated with such qualitative studies apply (Yin 2014). Due to the chosen study design, i.e., the methodology of semistructured expert interviews, it is possible that subjective assessments by the authors of the study had an influence on the results. However, the discussion of the interview protocols and their approval by the experts was an attempt to minimize this influence. In the present study, managers from various different departments in companies were interviewed as experts. Future research could use a survey of members of the management boards or supervisory boards, to investigate whether similar assessments emerge. In addition to such further qualitative studies, the relevance of the various challenges, in particular those that have received 
little attention in empirical studies to date, could be examined by means of large-scale surveys. A further limitation is that only companies with headquarters in Germany and Switzerland were included in the study. A more international comparison would constitute a useful approach to gaining deeper insights.

\section{Conclusion}

The present study provides in-depth insights into the advantages that companies consider in implementing a purpose, but also into the challenges associated with this approach that prevent its further dissemination and use. This applies, for example, to the question of how to deal with employees who do not support the company's purpose. The sometimes critical attitude of investors to the implementation of a purpose that may not support the profit target is also a problem, as is the question of how to deal with situations in which the actions of supply chain partners conflict with and disrupt the company's purpose.

Based on the experiences of the interviewees, the present paper addresses ways to deal with these problems. Various forms of cooperation with NGOs, for example, can help to advance the achievement of the company purpose and its communication. Innovative legal forms can also constitute another appealing and constructive approach for companies with hybrid target systems. Further research is needed to develop concepts that enable companies to be both commercially successful and to implement and align their activities with their purpose. Current discussions show that a need for this is increasingly being recognized in companies.

\section{Appendix}

\section{Interview Guide}

Part One: Introductory Questions

1. Can you please explain your function and position in your company? How long have you been working there?

2. Is a purpose implemented in your company? If yes, what?

3. Why did your company choose this particular purpose?

4. If there is no purpose implemented in your company, have you considered whether such a purpose should be defined in your company?

5. What was the decision process like? Who gave the initial impulse, who finally made the decision?
Second part: Opportunities and advantages of PurposeLed Companies Compared to Traditional Companies

6. Which of the following opportunities or advantages do you consider as relevant? Why? Do you see further opportunities or advantages? Please assign a number between 1 and 5 to the following items: from $1=$ "fully agree", 2 = "somewhat agree", $3=$ "neither nor", $4=$ somewhat disagree" to $5=$ "disagree". Can you briefly explain your answer?

- Higher financial success

- Higher employee motivation

- Higher attractiveness for applicants

- Higher customer loyalty

Part Three: Challenges of Purpose-Led Companies Compared to Traditional Companies

7. Which of the challenges listed below do you consider as relevant? Why? Do you see any other challenges? Please assign a number between 1 and 5 to the following items: from 1 = "fully agree", 2 ="somewhat agree", $3=$ "neither nor", $4=$ somewhat disagree" to $5=$ "disagree". Can you briefly explain your answer?

- Conflict with financial goals

- Deterrence of financially-oriented investors

- Negative employee attitude

- Contradictory stakeholder requirements

8. How to deal with employees who have not internalized the purpose?

Funding Open Access funding enabled and organized by Projekt DEAL.

\section{Declarations}

Conflict of interest On behalf of all authors, the corresponding author states that there is no conflict of interest.

Open Access This article is licensed under a Creative Commons Attribution 4.0 International License, which permits use, sharing, adaptation, distribution and reproduction in any medium or format, as long as you give appropriate credit to the original author(s) and the source, provide a link to the Creative Commons licence, and indicate if changes were made. The images or other third party material in this article are included in the article's Creative Commons licence, unless indicated otherwise in a credit line to the material. If material is not included in the article's Creative Commons licence and your intended use is not permitted by statutory regulation or exceeds the permitted use, you will 
need to obtain permission directly from the copyright holder. To view a copy of this licence, visit http://creativecommons.org/licenses/by/4.0/.

\section{References}

Accenture. 2018. To Affinity and Beyond. From me to we, the rise of the purpose-led brand. https://www.accenture.com/_acnmedia/ thought-leadership-assets/pdf/accenture-competitiveagility-gcprpov.pdf. Accessed 20 Jan 2021.

Airbus. 2021. Airbus Purpose. https://brand.airbus.com/our-brand/ airbus-purpose.html. Accessed 20 Jan 2021.

ANA. 2020. The B2B Purpose Paradox. https://www.ana.net/getfile/ 29416. Accessed 20 Jan 2021.

Annweiler, Bård. 2018. Purpose is at the core of branding. Journal of Brand Strategy 7 (3): 214-224.

Asmussen, Bjoern, Sally Harridge-March, Nicoletta Occhiocupo, and Jillian Farquhar. 2013. The multi-layered nature of the internetbased democratization of brand management. Journal of Business Research 66 (9): 1473-1483. https://doi.org/10.1016/j.jbusr es.2012.09.010.

Bartlett, Christopher A. and Sumantra Ghoshal. 1994. Changing the role of top management: Beyond strategy to purpose. Harvard Business Review 79-88.

Bauer, Joanne, and Elizabeth Umlas. 2017. Making corporations responsible: The parallel tracks of the B corp movement and the business and human right movement. Business and Society Review 122 (3): 285-325. https://doi.org/10.1111/basr.12118.

Bauer, Tayla N., Elizabeth Wolfe Morrison, and Ronda Roberts Callister. 1998. Organizational socialization: A review and directions for future research. Research in Personnel and Human Resource Management 16: 149-214.

Bueren, Eckart. 2019. Sustainable Finance. Zeitschrift Für Unternehmens- Und Gesellschaftsrecht 48: 813-875. https://doi.org/10. 1515/zgr-2019-0022.

Busch, Christian. 2021. Towards an enlightened form of capitalism: The changing role of private organizations in the context of global affaires. In The future of global affairs, ed. C. Ankersen and W.P.S. Sidhu. https://doi.org/10.1007/978-3-030-56470-4_5.

By, Rune Todnem. 2021. Leadership: In Pursuit of Purpose. Journal of Change Management 21 (1): 30-44. https://doi.org/10.1080/ 14697017.2021.1861698.

Cardona, Pablo, Carlos Rey, and Nick Craig. 2019. Purpose-driven leadership. In Purpose-driven organizations management ideas for a better world, ed. Carlos Rey, Miquel Bastons, Phil Sotok, 57-71. Palgrave Macmillan. https://doi.org/10.1007/ 978-3-030-17674-7_5.

Collins, Hilary, and Cosette Saliba. 2020. Connecting people to purpose builds a sustainable business model at Bark House. GBOE 39 (3): 29-37. https://doi.org/10.1002/joe.21992.

CVS Health. 2020. Tobacco-free for five years. https://cvshealth.com/ thought-leadership/tobacco-free-for-five-years. Accessed $20 \mathrm{Jan}$ 2021.

Dahlmann, Frederik, Wendy Stubbs, Rob Raven, and Joao Porto de Albuquerque. 2020. The 'purpose ecosystem': Emerging private sector actors in earth system governance. Earth System Governance. https://doi.org/10.1016/j.esg.2020.100053.

Daimler. 2021. https://www.mercedes-benz.com/de/unternehmen/ purpose/. Accessed 20 Jan 2021.

Deloitte. 2014. Culture of purpose - Building business confidence; driving growth 2014 core beliefs \& culture survey. https://www2. deloitte.com/content/dam/Deloitte/us/Documents/about-deloi tte/us-leadership-2014-core-beliefs-culture-survey-040414.pdf. Accessed 20 Jan 2021.

DDI. 2018. Global Leadership Forecast 2018, 25 Research insights to fuel your people strategy. https://www.ddiworld.com/research/ global-leadership-forecast-2018. Accessed 20 Jan 2021.

Du, Shuili, C.B. Bhattacharya, and Sankar Sen. 2007a. Convergence of Interests-Cultivating Consumer Trust Through Corporate Social Initiatives. Advances in Consumer Research 34: 687.

Du, Shuili, C.B. Bhattacharya, and Sankar Sen. 2007b. Reaping relational rewards from corporate social responsibility: The role of competitive positioning. International Journal of Research in Marketing 24 (3): 224-241.

Edelmann. 2012. Edelmann goodpurpose 2012 Global Consumer Survey.

European Commission. 2011. Communication from the Commission to the European Parliament, the Council, the European Economic and Social Committee and the Committee of the Regions. A renewed EU strategy 2011-14 for Corporate Social Responsibility. Brussel, 25 Oct 2011.

EY Beacon Institute. 2016. The state of the debate on purpose in business. https://assets.ey.com/content/dam/ey-sites/ey-com/en_gl/ topics/purpose/ey-the-state-of-the-debate-on-purpose-in-busin ess.pdf . Accessed 20 Jan 2021.

EY Beacon Institute. 2017. How can purpose reveal a path through disruption? https://assets.ey.com/content/dam/ey-sites/ey-com/ en_gl/topics/purpose/purpose-pdfs/ey-how-can-purpose-reveala-path-through-uncertainty.pdf. Accessed 20 Jan 2021.

Fan, Ying. 2005. Ethical branding and corporate reputation. Corporate Communications: An International Journal 10 (4): 341-350. https://doi.org/10.1108/13563280510630133.

Faria, Pedro, and Nicole Labutong. 2019. A description of four sciencebased corporate GHG target-setting methods. Sustainability, Accounting, Management and Policy Journal 11 (3): 591-612. https://doi.org/10.1108/SAMPJ-03-2017-0031.

Fink, Franziska, and Michael Moeller. 2018. Purpose Driven Organizations: Sinn - Selbstorganisation - Agilität. Stuttgart: SchäfferPoeschel Verlag.

Flick, Uwe (eds.). 2018. The SAGE handbook of qualitative data collection. Los Angeles: SAGE.

Fleischer, Holger. 2021. Corporate purpose: A management concept and its implications for company law. https://ecgi.global/conte nt/working-papers. Accessed 20 May 2021.

Fontán, Clara, Ángel Alloza, and Carlos Rey. 2019. (Re)Discovering organizational purpose. In Purpose-driven organizations management ideas for a better world, ed. Carlos Rey, Miquel Bastons, Phil Sotok, 107-118. Palgrave Macmillan. https://doi.org/ 10.1007/978-3-030-17674-7_5.

Fröndhoff, Bert, and Michael Scheppe. 2019. Der Sinn hinter der Arbeit: So benennen die 30 DAX-Konzerne ihren „Purpose”. Handelsblatt, April 18. https://www.handelsblatt.com/unter nehmen/management/handelsblatt-umfrage-der-sinn-hinter-derarbeit-so-benennen-die-30-dax-konzerne-ihren-purpose/24231 702.html?ticket=ST-96137-ICbubpRfAVLuwH10ezWg-ap6. Accessed 13 May 2021.

Gartenberg, Claudine, Andrea Prat, and George Serafeim. 2019. Corporate purpose and financial performance. Organization Science 30 (1): 1-18. https://doi.org/10.1287/orsc.2018.1230.

George, Gerard, Martine R. Haas, Anita M. McGahan, Simon J.D.. Schillebeeckx, and Paul Tracy. 2021. Purpose in the for-profit firm: A review and framework for management research. Journal of Management. https://doi.org/10.1177/01492063211006450.

Häfner, David, Florian Kiesel, and Lucas Wirthmann. 2017. What do we know about socially responsible investments? Zeitschrift Für Umweltpolitik \& Umweltrecht 40: 299-331. 
Hajdas, Monika, and Ryszard Kleczek. 2021. The real purpose of purpose-driven branding: Consumer empowerment and social transformations. Journal of Brand Management. https://doi.org/ 10.1057/s41262-021-00231-z.

Harvard Business Review. 2015. The business case for purpose. Harvard Business Review. https://www.ey.com/Publication/vwLUA ssets/ey-the-business-case-for-purpose/\$FILE/ey-the-businesscase-for-purpose.pdf. Accessed 20 Jan 2021.

Helm, Sabrina. 2007. The role of corporate reputation in determining investor satisfaction and loyalty. Corporate Reputation Review 10: 22-27. https://doi.org/10.1057/palgrave.crr.1550036.

Hendersen, Rebecca, and Eric van den Steen. 2015. Why do firms have "purpose"? The firm's role as a carrier of identity and reputation. American Economic Review 105 (5): 326-330.

Höpner, Alex. 2018. „Wir stellen erstmalig den Sinn in den Mittelpunkt unserer Strategie". Handelsblatt, 3. August 2018. https://www. handelsblatt.com/unternehmen/industrie/siemens-chef-kaeserim-interview-wir-stellen-erstmalig-den-sinn-in-den-mittelpunktunserer-strategie/22876702.html?ticket=ST-525578-KiN9L Rsx531Z9Ve4292X-ap2. Accessed 13 May 2021.

Hsieh, Nien-hê, Marco Meyer, David Rodin, and Jens Van 'T Klooster. 2018. The social purpose of corporations. Journal of the British Academy 6 (1): 49-73. https://doi.org/10.5871/ jba/006s 1.049 .

IAG. 2021. Purpose and strategy. https://www.iag.com.au/about-us/ who-we-are/purpose-and-strategy. Accessed 20 Jan 2021.

ING. 2021. Purpose \& strategy. https://www.ing.com/About-us/Profi le/Purpose-strategy.htm. Accessed 20 Jan 2021.

Jones, Bruce. 2018. Mission versus purpose: What's the difference? Disney Institute Blog, October 23. https://www.disneyinst itute.com/blog/mission-versus-purpose-whats-the-difference/. Accessed 20 Jan 2021.

Jones, Robert. 2012. Five ways branding is changing. Guest Editorial. Journal of Brand Management 20: 77-79.

Kalkavan, Hakan. 2020. The relation between corporate social responsibility and financial performance: Reviewing empirical studies and discussing the ethical aspect. In Strategic outlook for innovative work behaviours. contributions to management science, ed. H. Dincer and S. Yüksel. Cham: Springer. https:// doi.org/10.1007/978-3-030-50131-0_10.

Kallio, Hanna, Anna-Maija. Pietilä, Martin Johnson, and Mari Kangasniemi. 2016. Systematic methodological review: Developing a framework for a qualitative semi-structured interview guide. Journal of Advanced Nursing 72 (12): 2954-2965. https://doi.org/10.1111/jan.13031.

Kautonen, Teemu, Simon J.D.. Schillebeeckx, Johannes Gartner, and Henri Hakala. 2020. The dark side of sustainability orientation for SME performance. Journal of Business Venturing Insights 14: e00198. https://doi.org/10.1016/j.jbvi.2020.e00198.

Kellogg's Company. 2021. Our vision \& purpose. https://www.kello ggcompany.com/en_US/our-vision-purpose.html. Accessed 20 Jan 2021.

Kiron, David, Gregory Unruth, Nina Kruschwitz, Martin Reeves, Holger Rubel and Alexander Meyer zum Felde. 2017. Corporate sustainability at a crossroads: Progress towards our common future in uncertain times. MIT Sloan Management Review \& Boston Consulting Group. https://sloanreview.mit.edu/proje cts/corporate-sustainability-at-a-crossroads/. Accessed 20 Jan 2021.

Kivimaa, Paula, Wouter Boon, Sampsa Hyysalo, and Laurens Klerkx. 2019. Towards a typology of intermediaries transitions: A systematic review and research agenda. Research Policy 48 (4): 1062-1075. https://doi.org/10.1016/j.respol.2018.10.006.

Köhler, Jonathan, et al. 2019. An agenda for sustainability transitions research: State of the art and future directions. Environmental Innovation and Societal Transitions 31: 1-32.
Kolk, Ans, and Francois Lenfant. 2016. Hybrid business models for peace and reconciliation. Business Horizons 59: 503-524.

Kramer, Markus. 2017. Brand purpose: The navigational code for growth. Journal of Brand Strategy 6(1-9).

Korn Ferry. 2016. People on a mission. https://www.kornferry.com/ content/dam/kornferry/docs/article-migration/Korn_Ferry_People_on_a_Mission_1219.pdf. Accessed 20 Jan 2021.

Levillain, Kevin, and Blanche Segrestin. 2019. From primacy to purpose commitment: How emerging profit with purpose corporations open new corporate governance avenues. European Management Journal 37 (5): 637-647. https://doi.org/10.1016/j.emj 2019.07.002.

Liden, Robert C., Sandy Wayne, and Raymond T. Sparrowe. 2000. An examination of the mediating role of psychological empowerment on the relations between the job, interpersonal relationships, and work outcomes. Journal of Applied Psychology 85 (3): 407-416. https://doi.org/10.1037/0021-9010.85.3.407.

Lies, Jan. 2020. Purpose-driven branding: Agile Markenführung als "Brand-Ucation." Marketing Review St. Gallen 4 (2020): 888-897.

Lies, Jan. 2021. Aesthetics risings from beauty to reputation management. Corporate Reputation Review 24: 105-115. https://doi.org/ 10.1057/s41299-019-00094-w.

LinkedIn and Imperative. 2016. Purpose at work 2016 global report. https://business.LinkedIn.com/content/dam/me/business/en-us/ talent-solutions/resources/pdfs/purpose-at-work-global-report. pdf. Accessed 20 Jan 2021.

Lleo, Alvaro, Miquel Bastons, Carlos Rey, and Fernando Ruiz-Perez. 2020. Purpose implementation: Conceptualization and measurement. https://doi.org/10.2139/ssrn.3630416.

Mac CormacHeather Haney, Susan. 2012. New corporate forms: One viable solution to advancing environmental sustainability. Journal of Applied Corporate Finance 24 (2): 49-56. https://doi.org/ 10.1111/j.1745-6622.2012.00378.x.

Mañas-Viniegra, Luis, Igor-Alejandro. González-Villa, and Carmen Llorente-Barroso. 2020. The corporate purpose of Spanish listed companies: Neurocommunication research applied to organizational intangibles. Frontiers in Psychology 11: 2108. https://doi. org/10.3389/fpsyg.2020.02108.

Michaelson, Christopher, Michael G. Pratt, Adam M. Grant, and Craig P. Dunn. 2014. Meaningful work: Connecting business ethics and organization studies. Journal of Business Ethics 121: 77-90. https://doi.org/10.1007/s10551-013-1675-5.

Mion, Giorgio, and Cristian R. Loza Aduui. 2020. Understanding the purpose of benefit corporations: An empirical study on the Italian case. International Journal of Corporate Social Responsibility 5: 4. https://doi.org/10.1186/s40991-020-00050-6.

Miralles-Quiros, Maria, Jose del Mar, Luis Miralles-Quiros, and Irene Guia Arraiano. 2017. Sustainable development, sustainability leadership and firm valuation: Differences across Europe. Business Strategy and the Environment 26: 1014-1028. https://doi. org/10.1002/bse.1964.

Mishra, Oly. 2020. Communicating a company's higher purpose to conscious consumers through online behavioural advertising. The Marketing Review 20 (1-2): 93-108.

Mitchell, Alan. 2012. McKitterick's conundrum. Journal of Brand Management 20 (2): 80-95. https://doi.org/10.1057/bm.2012.52.

Muñoz, Pablo, Gabriella Caccioitti, and Boyd Cohen. 2018. The double-edged sword of purpose-driven behavior in sustainable venturing. Journal of Business Venturing 33 (2): 149-178. https:// doi.org/10.1016/j.jbusvent.2017.12.005.

Nestlé. 2021. About Us. https://www.nestle.com/aboutus. Accessed 20 Jan 2021.

Nga Wai Chan, Andrea. 2015. Social support for improved work integration: Perspectives from Canadian social purpose enterprises. 
Social Enterprise Journal 11 (1): 47-68. https://doi.org/10.1108/ SEJ-07-2014-0033.

Nicholson, Nigel. 1984. A theory of work role transitions. Administrative Science Quarterly 29 (2): 172-191. https://doi.org/10.2307/ 2393172.

Oechsle, Sixtux, and Tom Henderson. 2000. Identity: An exploration into purpose and principles at shell. Corporate Reputation Review 3 (1): 75-77. https://doi.org/10.1057/palgrave.crr.15401 01.

Oechsle III, Sixtus J. 2002. Brands and broadband-A communications opportunity. Corporate Reputation Review 5(2/3): 176-191. https://doi.org/10.1057/palgrave.crr.1540173.

Okafor, Anthony, Bosede Ngozi Adeley, and Michael Adusei. 2021. Corporate social responsibility and financial performance: Evidence from US tech firms. Journal of Cleaner Production 292: 126078. https://doi.org/10.1016/j.jclepro.2021.126078.

Patagonia. 2021. Our reason for being. https://www.patagonia.com.au/ pages/our-mission . Accessed 20 Jan 2021.

Pechmann, Jann, Silke Kreiling and Victoria Schilling. 2019. Purpose: Von Buzz zu Business. https://www.different.de/publikationen/ purpose-von-buzz-zu-business/. Accessed 20 Jan 2021.

Pinney, Chris, Sophie Lawrence, and Stephanie Lau. 2019. Sustainability and capital markets-Are we there yet? Journal of Applied Corporate Finance 31 (2): 86-92. https://doi.org/10.1111/jacf. 12350.

Philips. 2021. Our strategy. https://www.philips.com/a-w/about/compa ny/our-strategy. Accessed 20 Jan 2021.

Pontefract, Dan. 2017. Stop confusing CSR with purpose. Forbes, November 18. https://www.forbes.com/sites/danpontefract/ 2017/11/18/stop-confusing-csr-with-purpose/\#6a524dac3190. Accessed 20 Jan 2021.

Porter Novelli. 2019. Feeling purpose. https://static1.squarespace.com/ static/56b4a7472b8dde3df5b7013f/t/5ce6eb8c15fcc0076a87 4b15/1558637485726/Biometrics+Research+FINAL+Single+ Pages.pdf. Accessed 20 Jan 2021.

Pratt, Michael G. and Blake E. Ashforth. 2003. Fostering meaningfulness in working and at work. In Positive organizational scholarship: Foundations of a new discipline, ed. K.S. Cameron, J.E. Dutton, and R.E. Quinn. Berret-Kohler, 309-327. San Francisco.

Pruzan, Peter. 2001. Corporate reputation: Image and identity. Corporate Reputation Review 4: 50-64.

PWC. 2016. Putting purpose to work: A study of purpose in the workplace. https://floridacommunity.com/wp-content/uploads/ 2016/06/Putting-Purpose-to-Work-Purpose-Survey-Report.pdf. Accessed 20 Jan 2021.

Quinn, Robert E., and Anjan V. Thakor. 2018. Creating a purposedriven organization. Harvard Business Review July-August 78-85.

Radley Yeldar. 2016. Fit for purpose 2016. https://www.rankingthe brands.com/PDF/Fit\%20For\%20Purpose\%20Index\%20Top\% 20100\%202016.pdf. Accessed 20 Jan 2021.

Radley Yeldar. 2018. Fit for purpose. http://rypurpose.com. Accessed 20 Jan 2021.

Rode, Verena, and Christine Vallaster. 2005. Corporate branding for start-ups: The crucial role of entrepreneurs. Corporate Reputation Review 8 (2): 121-135.

SBTi. 2020. Science-based target setting manual version 4.1. https:// sciencebasedtargets.org/wp-content/uploads/2017/04/SBTimanual.pdf. Accessed 20 Jan 2021.

Segrestin, Blanche, Kevin Levillain, and Armand Hatchuel. 2015. A purpose-driven theory of the corporation? The nature and governance of the corporation. WINIR. Lugano, Switzerland, April 2015.

Segrestin, Blanche, Kevin Levillain, and Armand Hatchuel. 2016. Purpose-driven corporations: how corporate law reorders the field of corporate governance. European Academy of Management Conference (EU- RAM 2016). Paris, June 2016.
Southwest. 2020. Purpose, vision, and the southwest way. http://inves tors.southwest.com/our-company/purpose-vision-values-andmission. Accessed 20 Jan 2021.

Steenberg, Jan, and Rakesh Sharma. 2020. The new normal will require a new strategic approach to the ciscular economy. The time is right for a purpose-driven supply chain. Supply Chain Management Review July/August 9-11.

Stroehle, Judith C., Kazbi Soonawalla, and Marcel Metzner. 2019. How to measure performance in a purposeful company? Analysing the Status Quo. British Academy, Future of the Corporation Working Paper Series. https://doi.org/10.2139/ssrn.3504530.

Stubbs, Wendy. 2017. Sustainable entrepreneurship and B corps. Business Strategy and the Environment 26 (3): 331-344.

Swaminathan, Vanitha, Alina Sorescu, Jan-Benedict. Steenkamp, Thomas Clayton Gibson. O'Guinn, and Bernd Schmitt. 2020. Branding in a hyperconnected world: Refocusing theories and rethinking boundaries. Journal of Marketing 84 (2): 24-46. https://doi.org/10.1177/0022242919899905.

The British Academy. 2019. Principles for Purposeful Business. https:// www.thebritishacademy.ac.uk/publications/future-of-the-corpo ration-principles-for-purposeful-business/. Accessed 20 Jan 2021.

The Energy Project and Harvard Business Review. 2014. The human era @ work. https://uli.org/wp-content/uploads/ULI-Documents/ The-Human-Era-at-Work.pdf. Accessed 20 Jan 2021.

Unilever. 2021. Our strategy for sustainable growth. https://www.unile ver.com/sustainable-living/our-strategy/. Accessed 20 Jan 2021.

Vilá, Omar R., and Sundar Bharadwaj. 2017. Competing on social purpose. Harvard Business Review September-October.

Villela, Malu, Sergio Bulgacov, and Glenn Morgan. 2019. B Corp Certification and Its Impact on Organizations Over Time. Journal of Business Ethics. https://doi.org/10.1007/s10551-019-04372-9.

White, Andrew, Basak Yakis-Douglas, Heli Helanummi-Cole, and Marc Ventresca. 2017. Purpose-Led Organization: "Saint Antony" reflects on the idea of organizational purpose, principle and practice. Journal of Management Inquiry 26: 101-107. https://doi.org/10.1177/1056492616647481.

Witschey, Jim, Emerson Murphy-Hill, and Shundan Xiao. 2013. Conducting interview studies: Challenges, lessons learned, and open questions. In Conducting empirical studies in industry (CESI), 2013 1st International Workshop on IEEE, 51-54.

Yin, Robert K. 2014. Case study research design and methods, 5th ed. CA: Thousand Oaks.

Zappos.com AG. 2021. About us. https://www.zappos.com/about/. Accessed 20 Jan 2021.

$\mathrm{Zu}$, Liangrong. 2019. Purpose-driven leadership for sustainable business: From the perspective of Taoism. International Journal of Corporate Social Responsibility 4: 3. https://doi.org/10.1186/ s40991-019-0041-z.

Publisher's Note Springer Nature remains neutral with regard to jurisdictional claims in published maps and institutional affiliations.

Anette von Ahsen is an Associate Professor at the Chair of Auditing \& Accounting at Technical University of Darmstadt, Germany. Her research interest includes sustainability management and reporting of companies.

Kevin Gauch is a Research Assistant at the Chair of Auditing \& Accounting at Technical University of Darmstadt, Germany. His research interest includes corporate governance and reporting of companies. 